\title{
The Context of the Melodrama Cycle Hippodamia by Jaroslav Vrchlický and Zdeněk Fibich
}

\author{
Věra Šustíková, Jiří Petrdlík
}

As the creator of the first and only trilogy of music dramas, Zdeněk Fibich ranks among the most progressive artists of European music at the beginning of the 1890s. The fact that his example was not followed merely testifies to the uniqueness of his talent. ${ }^{1}$

Fibich's Romantic spirit was captivated by the symmetry and simplicity of antiquity as well as by the magnificence of its human emotion. The opera Nevěsta messinská [The Bride of Messina] was his first work on themes of antiquity; he sensed that it was necessary to go still further. Despite the lackluster response to his literary operas, in the interest of greater dramatic effect he set about to search for material for a scenic melodrama that would present the opposing forces of the Hellenic world-reason and passion-in exalted form. The form of the melodrama provided a harmonically reciprocal proportion as the bearer of momentous thought and emotion. Fibich finally found such dramatic material in Vrchlickýs Hippodamia. ${ }^{2}$ The subtext of the epic plot includes the conflicts between love and hatred, erotic passion and tender feeling, the duty of the sovereign and the desire for human happiness. The axis of the trilogy is the relationship of Hippodamia and Pelops, prominent representatives of two different cultures.

1 Otakar Hostinský had to acknowledge that Fibich's contribution was a victory over all those theorists who had assumed that this form definitively belonged to the past.

2 Vrchlický originally created Smrt Hippodamie [Hippodamia's Death] (1883) as a play and did not anticipate that it would be set to music. He returned to this theme with Námluvy Pelopovy [The Courtship of Pelops] (1887). Smír Tantaluv [The Atonement of Tantalus]was created as a libretto for Fibich. The two parts that were already finished were revised, according to Fibich's recollections; Smrt Hippodamie in particular went through many changes. The result was one of the best Czech libretti. There was an attempt to create the text of Hippodamia as an independent entity, but its performance as such demonstrated that the text alone could not serve as an independent work. As Vladimír Hudec has observed in his publications about Fibich, the composer's setting sought to realize conceptual, dramatic, and particularly tectonic aspects of the possibilities given by the shape of Vrchlický's dramatic poem. Hence, Vrchlický's work as a separate entity presents a quite different effect than Fibich's melodrama does. 
The introductory section of Námluvy Pelopovy is an exposition of the entire trilogy: it presents Pelops as a typical representative of Hellenistic Greece and demonstrates how different he is from the so-called barbaric world in which riches have supreme value and are the driving force for human life; all else is subordinated to riches. The differences between the two cultures are depicted in Pelop's dialogues with King Oinomaos and the slavish Myrtillos. Nevertheless, his conversations with his own servant Jolos demonstrate that the servant's views do not even come close to Pelop's distinctive ideas; they are much nearer to the views of the barbaric world. Myrtillos, Oinomaos's charioteer, is also somewhat more "barbaric" than his lord, but he is an astute éminence grise who is merely waiting for an opportunity. The bridge between the two cultures is set afire by the passionate love of Pelops and Hippodamia, which conquers all obstacles at first-including Hippodamia's sacrifice of the life of her own father for Pelops' life; she willingly abandons her own culture and follows Pelops to his kingdom. But their unrestrained, passionate love is the cause and beginning of evil: Hippodamia commits treason against her father; Pelops betrays his beloved wife Axioche and, as his most serious crime, murders his presumed rival Myrtillos. (It is only revealed at the end of Smír Tantaliv that Myrtillos has survived.)

The second part, Smir Tantaluv, presents the reverse situation. Hippodamia is aware that she is regarded as an inferior "barbarian" in the Hellenistic world, but attempts to find her own place there. Motivated principally by a fear of losing Pelops' love, she fights openly with family and friends who have emotional ties to him; she is driven to pathological jealousy and many conflicts. Similarly, Pelops is driven to the idea that the very same attribute that he admired in Hippodamia in her own surroundings damns her in the end in confrontation with his world. Humiliated and offended, Hippodamia becomes ironic, aloof and reproachful. Two differing views of the same reality underlie the family quarrels. "Who is more of a barbarian here?" asks the long-suffering Hippodamia.

In retrospect, we also learn why Pelops went out into the world in the first part of the trilogy. He wanted to obtain the advice of the Delphic oracle about how he could conciliate the gods for the monstrous crime of his father Tantalus. Tantalus committed his crime because he desired to be a god, but afterwards he was not really better off than the barbarian Oinomaos. Vrchlický implies that "civilized" society is not substantially different from the "barbarian" in this respect; it merely displays an outward veneer that gives, at first glance, an impression of exquisite breeding, education, and culture. The doubts and pangs of conscience that burden civilized people do not insure them from committing further crimes. Pelops, the heir of his father's guilt according to the tradition of antiquity, ends up like Tantalus. Even his sincere attempt to rectify old crimes leads to the emergence of new crimes and thus to a new curse. Nevertheless, he believes that Hippodamia is the cause of his unhappiness. Despairing, he tries to obtain certainty about her guilt. He leaves to call forth the spirits of the dead, but learns that the inexorable Oinomaos is calling for Hippodamia's death.

Smrt Hippodamie, the conclusion of the trilogy, takes place twenty years later as the next generation enters the plot. The three sons, brought up in the same surroundings, are nevertheless bearers of the differing qualities of their families, and their tragedy continues. 
They commit crimes in the name of honor, culminating in fratricide. The entire drama of the life of the main protagonists comes to a climax at this point. Now Hippodamia wants to sacrifice everything to preserve her children. She asks Pelops to sacrifice the most valuable thing that remains to her, her honor, and to forget all the insults and humiliations she has suffered. But it is already too late for Pelops to do so. His cold rejection compels her to a desperate, murderous attack on the very person that she had loved so intensely. The return to the root of all evil is now represented by Myrtillos, who has come to take revenge. It was believed that he had perished under the hand of Pelops, and that Pelops' marriage would have been called into question if he had survivied. Pelops had never learned the truth about the relationship of Myrtillos with Hippodamia. Now Hippodamia understands what further suffering she can expect from the gods for Pelops' sake, and prefers to kill herself. She fulfils her destiny and Oinomaos is appeased. As the heir of his father Tantalus, Pelops is guilty of an offense against hospitality, and even of killing his host. He has become the heir of his father's infinite torments from a bad conscience-"the agonies of Tantalus".

Vrchlický's story is entirely free, taking its plot from a historically unsubstantiated myth from antiquity. It evokes a romantic illusion of "humanity in general"; the spectator in every era can resolve his or her own problems on its model and discover the meaning of life with his or her own understanding of truth. Antiquity becomes merely a backdrop for the age-old psychological conflict of understanding and passion. The text also presents wider problems of the values of life, such as tolerance and cultural coexistence.

Vrchlický emphasized the grandeur of the themes of antiquity by using a Czech form of blank verse. His language has a sensuous beauty of sound and the form of the word. ${ }^{3}$ His thematic construction is exceptionally balanced with respect to the action, psychological characterization, the drama of conflict, and lyrical moments of reflection. Perhaps for this reason this remarkable work is considered to be one of the best Czech libretti, even though its requirements make it unsuitable to present as spoken theatre. ${ }^{4}$ The highest priority of Fibich's music is giving shape to the characters of the dramatic roles, the action, and the dramatic effect. He depicts the characters and their transformations with the aid of characteristic motives combined for dramatic situations and reprised as reminiscences and symbols. His musical motives do not only refer to the dramatic roles, but also events

\footnotetext{
Vrchlickýs libretto was so highly esteemed by his contemporaries (F. X. Šalda pointed out the poet's distinctive, thoughtful creativity, revelling in the Parnassian beauty of the form and sound of words, and called him a Renaissance poet), that the entire Hippodamia trilogy was given at the Národní divadlo [by its ensemble] for Vrchlický's fortieth birthday, and Vrchlický himself wrote in a letter to Ed. Albert on 21 February 1893 that he had been called on stage thirty times and that it had been beyond human strength. Fibich was respected along with Vrchlický as a matter of course, but it is necessary to say that he was never sufficiently appreciated as an actual asset, and that this underestimation has persisted to this day in occasional studies of the undetectably many nuances that this exceptional work contains.

4 In 1913, the Národní divadlo in Prague presented Vrchlický's play without Fibich’s music. However, this effort by Kvapil was not successful.
} 
and issues; there are motives of prophecy, fate, curses, glory, competitions, hospitality, funerals, judgments, and so forth. Their chief purpose is to illuminate interrelationships. Motives of love and hatred are transformed and varied in countless forms to reflect the transformations in Hippodamia's own life. ${ }^{5}$ Fibich musically records the emotional relationships of people as well as the changes and development of their dramatic characters and for this reason his characters are more lifelike than Vrchlickýs, and the entire work gains strength from a dynamism, not only with an increase in expressive techniques, but also psychological intensification. The basis for Vrchlický's realization of the libretto concept-the age-old dispute between reason and passion-is quite different from Fibich's. Vrchlický usually took the side of the world of reason; he perceives the principal character as Pelops and identifies with his typically male stance in his love relationship with Hippodamia. On the other hand, Fibich's enormous enthusiasm enables him to understand, empathize, and defend each of the characters of the drama. ${ }^{6}$

As a Romantic, Fibich was profoundly drawn to the melodic aspect of composition in a way fully in conformance with his use of characteristic motives. He is composing at the height of thematicism, and supporting it with tonal functions of harmonic relationships that tend toward so-called "endless melody". He does not avoid programmatic tone color (for example, the turbulent sea at the close of Námluvy Pelopovy, and the evocation of the rhapsodic performance of the old singer in the introduction of Smrt Hippodamia). Fibich strives to maximize the through-composed aspect of the formal structure, and for this reason the musical current in itself is seldom divided into sections on the basis of expressivity. Its division into entrances and scenes is taken from the form of Vrchlický's text.

Fibich is fundamentally a symphonist in his use of instrumental resources. He does not perceive the orchestra as the summation of three instrumental groups, and thus of three fundamental sonic possibilities ${ }^{7}$, but makes an effort to intersperse individual instruments with regard to which instrumental group they belong. The score as a whole

5 Hippodamia has penetrating emotion and is passionate, dreaming, variable-she is transformed from a charming, wild, and unruly girl, secretly longing for love and affection, to an intensely jealous woman, insulted and humbled in her womanhood. She is presented as a heroine, a self-reliant and majestic ruler, and eventually as a mother who is capable of sacrificing everything for the sake of her children. The tragedy of her life is her desire for love, for which she pays too high a price.

6 A typical example is Tantalus. He is viewed by Pelops as a suffering father, worthy of compassion, but Hippodamia sees him as an old man who has gone mad from fear of his own crimes and does not deserve pity. In his musical characterization of the characters, Fibich tends unambiguously to the first view. The characteristic motives of Tantalus, depicting kingly glory, hope, uneasiness, agonizing forebodings and deliverances as well as the climactic motive of his redemption, unambiguously portray this venerable old man with appropriate empathy and understanding. With his suffering, he redeems his guilt and earns respect.

7 Although Fibich is traditionally identified as a follower of Bedřich Smetana, his orchestration in Hippodamia is markedly different from Smetana's. Smetana has a tendency to orchestrate by instrumental groups; he often works with the string section, woodwind harmony and brass instruments as self-sufficient entities. These three fundamental instrumental groups are often complemented with percussion and harp. 
evokes an impression of superlative through-composed continuity, richness and tone color. ${ }^{8}$ The compactness of Fibich's instrumentation is emphasized by the fact that he extends the boundaries of instrumental ranges and uses extreme dynamic levels only during particularly intense moments of the plot. His originality in sound also leads him to add instruments to the standard instrumentation of the symphonic orchestra that were not in common use at the time, such as the tam-tam and bass clarinet. In keeping with the requirements of the stage, he takes advantage of possibilities for acoustic effects provided by the theatre itself (for example, the trumpets behind the scene in Smrt Hippodamie).

The composer had to cope with the practical requirements of theatrical representation. For this reason, there are relatively many extensive passages without words throughout the trilogy, and Fibich must, during composing, proceed without a text (but not without regard to the dramatic situation). There are moments of various processions, exits, rearrangements, scene changes, and so forth. ${ }^{9}$

The relationship of word and music is that of free melodrama (with minor exceptions such as the chorus of princes in Smir Tantaluv, where the rhythm for the recitation is precisely stipulated); the correspondence to the intonation, meter, and rhythm of the text is not strictly observed. At first glance this approach to melodrama would seem to give the composer an opportunity for greater freedom with the musical aspects, but the freer relationship between text and music is illusory. Fibich was very skilfully taking into account the fact that every theatrical interpreter might have a slightly different cadence of speech. When composing he approached this problem as an opera composer would with frequent fermatas, caesuras, and instructions such as colla parte, so that the director could respect the actual course of the theatrical action, and could create sufficient room for the artistic stylization of the actors. The music of the melodrama surely has its own identity, but it is subordinated to the cadence of speech, emphasizing rather than disrupting it. Fibich's refined compositional technique is concretely shown by his precise formulation of dynamic, tempo, and expression marks. Although the composer had to be aware from the beginning of his work that musical factors had to have a subordinate place in the composition, he never yielded with respect to details of preparing phrases, articulations, and their other aspects.

Fibich had an exceptional ability to solve the greatest problem: the syncretic fusion time. Time is an extremely important factor in music as well as in spoken acting performance, but it has entirely different constraints in these two genres..$^{10}$ It has already been mentioned that the composer solved the problem of such latitude in a practical way, following the example of operatic composers. Throughout the trilogy we find places resem-

8 As we often notice, for example in Dvořák's later opera Rusalka.

9 Of all these we should at least mention the entrance of Tantalus with his courtiers in the introduction of the second part of the trilogy, the Olympian march and the very original procession of judges in 5/4 meter in Smrt Hippodamie.

10 There is not enough space in this short essay for such an extensive and fundamental theme. Fibich clearly understood the constraints that Vrchlický's text placed on expression, form, and other aspects of his musical stream, and had to be doubly aware of temporal restrictions. 
bling recitative accompagnato, and long monologues whose musical form often resembles that of opera arias. And despite this resemblance, the fundamental level of the relationship of the music to the spoken or sung text is markedly different from that of opera. ${ }^{11}$ Although Fibich was directly limited by the temporal possibilities of the text, his inner sense of tempo and rhythm, as well as the properties of the formal sections, enabled him to succeed in finding a compositional style that respected the legitimacy of the duration of the spoken word but would not have a counterproductive effect on the music itself. He had infallible judgment for the duration of the musical realization of words, ${ }^{12}$ as well as for dramatic time of psychological and imitative action, theatrical cooperation and conflict inseparably joined with the dramatic dialogues. Hence, he was able to create scenic melodramas of ravishing dramatic strength.

The individual sections of all three parts of the trilogy have very balanced formal proportions, with distinctive emphases on dominant themes: the epic breadth of Námluvy Pelopovy, the lyrical intensity of Smír Tantaliv and the dramatic conclusion of Smrt Hippodamie.

Námluvy Pelopovy is the shortest in length. We encounter the dramatic roles and their musical characteristics for the first time here. The individual characteristic motives and themes are heard in their original crystallized shape. Its plot is not as complex, and the length and settings of the individual acts and scenes are not as contrasted with each other as in the other parts of the cycle.

Smir Tantaliv, the central part of the tryptich, is the most extended. The introductory act again functions as an exposition. Since new characters are introduced (for example, Tantalos and Axiocha) it is necessary to bring in new motivic / thematic material. Reminiscences and combinations of individual themes and motives begin to appear with the start of the second act; one of these motives is inherited from earlier events in Námluvy Pelopovy. ${ }^{13}$

Smrt Hippodamie has, to a striking degree, the function of a reprise. We are already familiar with most of its motivic/thematic material from the first two parts of the cycle. New characteristic motives describe the new dramatic roles (Chryssipos, Atreus, Thyestes, Airopa), but form only a lesser part of the motivic material. Symphonic interludes occupy more space here than they do in the preceding parts of the trilogy. One can observe a heightened concentration of characteristic motives at the close of Smrt Hippodamie as the drama comes to a climax and resolves the fates of many of the characters in a relatively short section. Its music provides a summation of the thematic material of the entire cycle

11 The composer must often repeat certain words (or a larger or smaller part of a sentence) to realize the great potential of the vocal lines, and to permit vocalization that is not possible in the spoken text.

12 As he had already shown in his concert melodramas.

13 Reprises occur at a culminating moment, such as the scene with the oracle in the fourth act, where Pelops calls forth the shadows of characters from previous scenes, each appropriately characterized through music. 
at the close of the trilogy..$^{14}$ But this section is far from a mechanical accumulation of thematic material; it is a highly artistic play with motives, transformed through variation to reflect the characters' new circumstances, the accumulation of events and combinations. These motives form a complex interrelationship of associations, recollections in a new light of knowledge and so forth that displays the interconnected correspondence of the music of the entire trilogy as well as the correspondence of ideas.

As a cycle Hippodamia is a work of incredible structural integrity; each section recalls earlier events and enables the next event. The necessary concentration of musical diction and the capabilities of the musical miniature combined to enable Fibich to create a great, monumental fresco. The perfect homogeneity of dramatic and musical expression intensifies the perception of the audience and the dramatic artists, so that they experience a remarkably intense emotional experience. The most amazing aspect of Fibich's approach to the libretto is that he is able to understand and empathize with every character, most of all from the perspective of the principal heroine; he supports her point of view throughout her complex, psychologically unfolding love relationship. The prime mover of Hippodama's strength is love; her tragedy consists in the fact that it is not possible for others to understand its substance. We clearly perceive that the Hippodamia trilogy, despite all of its problematic complexities, has an inner truth that captures our attention, moves us, and captivates us. Fibich's musical eroticism oscillates between the celebration of tender feeling and a sense of actual experience. In this cycle Fibich strongly reflected the Romantic position at the end of the nineteenth century with its psychological depths and extreme eroticism, of which he was the first and most significant representative in Czech music.

\section{Die ideellen Zusammenhänge des Zyklus Hippodamia von Zdeněk Fibich}

\section{Zusammenfassung}

Die Trilogie der Melodramen Hippodamia von Zdeněk Fibich nach einem Libretto von Jaroslav Vrchlický stellt ein einmaliges Werk nicht nur in der tschechsichen Kulturgeschichte, sondern auch im internationalen Kontext dar. Das Libretto Vrchlickýs haben bereits dessen Zeitgenossen entsprechend anerkannt und analysiert. Der Anteil Fibichs wurde zwar immer annerkant, doch nie genügend theoretisch ausgewertet. Die unzureichenden Kenntnisse der für dieses Werk bestimmenden musikalischen Struktur werden bei den seltenen Aufführungen deutlich, da die zahlreichen Feinheiten, die dieses außerordentliche Werk beinhaltet, nicht erkannt werden. Unser Beitrag will auf die unbekannten ideellen Zusammenhänge der Trilogie als Ganzes, und zwar vom philoso-

14 For that matter, the close of the Wagner tetralogy understandably evokes the same impression. 
phischen, psychologischen, dramatischen, aber auch rein literarischen und musikalischen Standpunkt aus aufmerksam machen.

Übersetzt von Vlasta Reiterrerová

\title{
Myšlenkové souvislosti cyklu Fibichovy Hippodamie
}

\begin{abstract}
Shrnutí
Fibichova melodramatická trilogie Hippodamie na libreto Jaroslava Vrchlického je unikátním dílem nejen v českých kulturních dějinách, ale i ve světovém kontextu. Vrchlického libreto bylo náležitě oceněno a teoreticky analyzováno již jeho vrstevníky. Fibichův přínos, ač vždy kladně ceněn, nebyl ve skutečnosti nikdy dostatečně teoreticky zhodnocen. Nedostatečné poznání určující hudební struktury se dodnes projevuje při ojedinělých nastudováních $\mathrm{v}$ neodhalenosti mnoha fines, které toto mimořádné dílo obsahuje. Náš př́spěvek chce upozornit na unikající myšlenkové souvislosti trilogie jako celku: po stránce filozofické, psychologické, dramatické, v rovině literární i hudební.
\end{abstract}

\section{Keywords}

Trilogy of scenic melodrama Hippodamia; Zdeněk Fibich; analysis of melodrama. 